\title{
PREFERENCE HETEROGENEITY AND INSURANCE MARKETS: EXPLAINING A PUZZLE OF INSURANCE
}

\author{
David M. Cutler \\ Amy Finkelstein \\ Kathleen McGarry \\ Working Paper 13746 \\ http://www.nber.org/papers/w13746
NATIONAL BUREAU OF ECONOMIC RESEARCH
1050 Massachusetts Avenue
Cambridge, MA 02138
January 2008

We are grateful to Liran Einav, Alex Muermann, Tomas Philipson, Michael Rothschild and participants and the NBER Insurance Meeting for helpful comments, and to the National Institutes on Aging for research support. The views expressed herein are those of the author(s) and do not necessarily reflect the views of the National Bureau of Economic Research.

NBER working papers are circulated for discussion and comment purposes. They have not been peerreviewed or been subject to the review by the NBER Board of Directors that accompanies official NBER publications.

(C) 2008 by David M. Cutler, Amy Finkelstein, and Kathleen McGarry. All rights reserved. Short sections of text, not to exceed two paragraphs, may be quoted without explicit permission provided that full credit, including $\odot$ notice, is given to the source. 
Preference Heterogeneity and Insurance Markets: Explaining a Puzzle of Insurance

David M. Cutler, Amy Finkelstein, and Kathleen McGarry

NBER Working Paper No. 13746

January 2008

JEL No. G22,I11

\begin{abstract}
$\underline{\text { ABSTRACT }}$
Standard theories of insurance, dating from Rothschild and Stiglitz (1976), stress the role of adverse selection in explaining the decision to purchase insurance. In these models, higher risk people buy full or near-full insurance, while lower risk people buy less complete coverage, if they buy at all. While this prediction appears to hold in some real world insurance markets, in many others, it is the lower risk individuals who have more insurance coverage. If the standard model is extended to allow individuals to vary in their risk tolerance as well as their risk type, this could explain why the relationship between insurance coverage and risk occurrence can be of any sign, even if the standard asymmetric information effects also exist. We present empirical evidence in five difference insurance markets in the United States that is consistent with this potential role for risk tolerance. Specifically, we show that individuals who engage in risky behavior or who do not engage in risk reducing behavior are systematically less likely to hold life insurance, acute private health insurance, annuities, long-term care insurance, and Medigap. Moreover, we show that the sign of this preference effect differs across markets, tending to induce lower risk individuals to purchase insurance in some of these markets, but higher risk individuals to purchase insurance in others. These findings suggest that preference heterogeneity may be important in explaining the differential patterns of insurance coverage in various insurance markets.
\end{abstract}

David M. Cutler

Department of Economics

Harvard University

1875 Cambridge Street

Cambridge, MA 02138

and NBER

dcutler@harvard.edu

Amy Finkelstein

Department of Economics

MIT E52-350

50 Memorial Drive

Cambridge MA 02142

and NBER

afink@mit.edu

\author{
Kathleen McGarry \\ Department of Economics \\ Dartmouth College \\ 305 Rockefeller Hall \\ Hanover NH 03755 \\ and NBER \\ kathleen.mcgarry@dartmouth.edu
}




\section{Introduction}

The textbook approach to insurance markets emphasizes the role of private information about risk in determining who purchases insurance. In the classic adverse selection model of Rothschild and Stiglitz (1976), individuals with higher expected claims buy more insurance than those with lower expected claims, who may be out of the market entirely. This basic prediction of asymmetric information models of a “positive correlation” between insurance coverage and accident occurrence has been shown to be robust to a variety of extensions to the standard framework (Chiappori and Salanie 2000, Chiappori et al. 2006).

Evidence of this positive correlation has been found in several insurance markets, particularly acute health insurance and annuities. ${ }^{1}$ Yet it many other insurance markets, those with more insurance appear to have the same or lower occurrences of the insured risk than those with less insurance. This phenomenon of “advantageous selection” has been documented in both large insurance markets such as life insurance (Cawley and Philipson 1999, McCarthy and Mitchell 2003) and Medigap insurance (Hurd and McGarry 1997, Ettner 1997, Fang et al. 2006), and in extremely thin markets such as long-term care insurance (Finkelstein and McGarry 2006) and reverse mortgages (Davidoff and Welke 2005). Moreover advantageous selection has been detected in an insurance market despite evidence that, as in the standard asymmetric information models, individuals also have private information about their risk type that is positively correlated with insurance demand (Finkelstein and McGarry, 2006). This discrepancy between theory and reality is even more striking given that moral hazard would tend to increase the risk occurrence of those with more insurance relative to those with less.

A potential explanation for this puzzle is that individuals may vary in their tolerance for risk in addition to their riskiness. When individuals are heterogeneous in their preferences as well as their risk type, the relationship between insurance coverage and risk occurrence can be of any sign (e.g. Fang et al., 2006, Finkelstein and McGarry 2006, Chiappori et al., 2007, Einav, Finkelstein and Schrimpf, 2007, Jullien et al.,

\footnotetext{
${ }^{1}$ Cutler and Zeckhauser (2000) review a large literature that tends to find a positive correlation between insurance coverage and risk occurrence in health insurance, although important exceptions such as Cardon and Hendel (2001) exist. Evidence of the positive correlation in annuities has been documented in the U.S. (Mitchell et al., 199), the U.K. (Finkelstein and Poterba 2002, 2004, and 2006) and in Japan (McCarthy and Mitchell 2003).
} 
2007). For example, individuals with lower tolerance for risk may not only demand more insurance but may also invest in activities that lower their expected claims. Such preference effects could offset standard asymmetric information effects to produce an advantageously selected equilibrium in which those with lower expected claims demand more insurance; as a result, the insurance market may exhibit over-insurance relative to the first best, rather than the under-insurance of classic, uni-dimensional adverse selection models (de Meza and Webb 2001).

When risk type is endogenous to risk tolerance, the correlation between preferences for insurance and expected claims need not be the same across markets. A risk averse person might invest in annuities and as well as engage in behaviors that decrease mortality; thus, for annuity purchasers there would be a positive correlation between insurance holdings and the insured risk of living a long time. The same person might also buy life insurance, however, leading to a negative correlation between the mortality risk that life insurance insures and life insurance holdings. Whether this potential countervailing preference effect materializes in practice, and whether it is large enough to offset the standard asymmetric information effects, is an empirical question. ${ }^{2}$

The existing evidence is consistent with a potentially important role for preference heterogeneity in understanding insurance market equilibria. A growing empirical literature has found evidence of substantial preference heterogeneity in insurance demand. Examples include automobile insurance (Cohen and Einav 2007), long-term care insurance (Finkelstein and McGarry 2006), reverse mortgages (Davidoff and Welke 2005), Medigap (Fang, Keane and Silverman 2006), and annuities (Einav, Finkelstein and Schrimpf 2007). These papers raise the possibility that heterogeneity in preferences may be as or more important than heterogeneity in risk in explaining insurance demand. They also suggest that the correlation between preferences for insurance and expected claims is not the same across markets. For example, in both annuities and auto insurance there is evidence that those with greater preferences for insurance have higher expected

\footnotetext{
${ }^{2}$ For example, it is not a priori clear that more risk averse individuals will invest more in activities that lower their expected claims. Preventive activity has a first order effect on the mean of the risk distribution; more risk averse individuals care about reducing the variance of this distribution, which may be positively or negatively correlated with the mean (see e.g. Dionne and Eeckhoudt, 1985 and Jullien et al., 1999).
} 
insurance claims, which would reinforce the standard asymmetric information effect (Einav, Finkelstein and Schrimpf, 2007; Cohen and Einav, 2007). However, in Medigap, long-term care insurance and reverse mortgages, those with higher preferences for insurance appear to have lower expected claims, creating offsetting advantageous selection (Fang et al, 2006, Finkelstein and McGarry 2006, Davidoff and Welke 2005). These findings raise the possibility that differences in the relationship between preferences and expected claims may help explain the observed differences in whether the market appears advantageously or adversely selected.

In this paper, we examine the relation between risky behaviors, insurance purchases, and risk occurrence in five different insurance markets: life insurance, acute health insurance, annuities, long-term care insurance, and Medicare supplemental insurance (Medigap). The analysis is highly complementary to the studies of individual insurance markets discussed above. Indeed, the same data source was used in earlier studies of long term care insurance (Finkelstein McGarry 2006) and Medigap (Fang et al. 2006), although we examine a different set of preference measures. Our main contribution is to show results across several different insurance markets using a common data set and empirical framework.

\section{Data and empirical framework}

Our analysis uses individual-level data from the Health and Retirement Study (HRS). We use the sample of people aged 51 to 61 in 1992 to examine the holding of term life insurance and private acute health insurance among prime-age individuals. We use a second HRS cohort, the Asset and Health Dynamics (AHEAD) sample, to examine Medigap insurance, long-term care insurance, and annuities among people aged 65 to 90 in 1995. We use the panel nature of these data to track mortality and nursing home outcomes for individuals in both panels through 2002. Table 1 presents key summary statistics for each sample. ${ }^{3}$ The average age in our 1992 HRS sample is 56 and in the 1995 AHEAD sample it is 79.

Our basic test is to examine how measures of risk tolerance are related to the occurrence of risk, and to whether the individual has insurance. Risk tolerance is not easily measured. We proxy for

\footnotetext{
${ }^{3}$ We use individual sample weights when calculating the means. The regressions presented later in the paper are unweighted.
} 
risk tolerance using five measures of behaviors that likely capture individual risk aversion:

smoking; drinking; job-based mortality risk; receipt of preventive health care; and use of seat belts. While each of these variables will reflect factors in addition to risk tolerance, results that are consistent across the variables suggest that risk tolerance is an important part of their variability.

We show results from two main types of analysis, designed to examine, respectively, the relationship between risk tolerance and insurance demand, and between risk toleranceand risk occurrence. We therefore estimate the following two equations by OLS:

$$
\begin{aligned}
& \mathbf{1} \text { (insurance })_{i}=\beta_{0}+\beta_{1} \text { Behavior }_{i}+X_{i} \Gamma+\varepsilon_{i} \\
& \text { Riskoccurence }_{i}=\alpha_{0}+\alpha_{1} \text { Behavior }_{i}+X_{i} \Pi+\eta_{i}
\end{aligned}
$$

In these equations $\mathbf{1}$ (insurance) ${ }_{i}$ is an indicator variable for whether the individual has a particular type of insurance, Riskoccurence ${ }_{i}$ is a measure of the occurrence of the risk the insurance in question would cover, Behavior $_{i}$ is one of our measures of risk tolerance, and $\mathrm{X}$ represents covariates. We describe each in more detail in turn.

\subsection{Insurance and risk occurrence measures}

We measure life insurance by whether the individual has term life insurance in the 1992 HRS; approximately 50 percent of the sample has this insurance. ${ }^{4}$ The risk occurrence measure for life insurance is whether the individual dies between 1992 and 2002; 13 percent die.

We measure acute private health insurance in the 1992 HRS by whether the individual has private health insurance through a current or former employer, a spouse's employer, or the non-group market; we exclude individuals who report coverage through a government program (e.g. Medicaid, Medicare, CHAMPUS or CHAMPVA) from the analysis of the acute health insurance market. About 86 percent of the sample has acute private health insurance; of this 86 , the vast majority ( 82 percent) have employment-related coverage. The corresponding risk occurrence measure is whether the individual reports any hospital use in the previous

\footnotetext{
${ }^{4}$ Another 21 percent own whole life insurance but no term policy. We focus on term life insurance which is a pure insurance vehicle, rather than whole life insurance which combines an insurance vehicle with a savings instrument.
} 
two years; 9 percent of the sample does. Hospital use is a strong predictor of medical expenses, which is the actual insured risk but which we do not directly observe in the data.

Our third measure of insurance, from the AHEAD, is whether an individual has an annuity in 1995. Approximately 7\% of the 1995 AHEAD sample has an annuity. ${ }^{5}$ The corresponding risk occurrence measure is the opposite of that for life insurance, specifically whether the individual survives from 1995 to 2002; 62 percent of the sample survives.

Fourth, we measure whether the individual has Medicare supplemental coverage (termed Medigap) in the 1995 AHEAD. Medigap policies cover many of the expenses not insured by Medicare, including coinsurance and deductibles. ${ }^{6}$ We define an individual as having Medigap if he has a (non-government provided) health insurance policy in addition to Medicare. ${ }^{7}$ Nearly 70 percent of the sample has Medigap coverage. Our corresponding risk occurrence measure is the medical expenses reported in 1995 arising from hospital and doctor visits that could have been covered by a Medigap policy; the mean is $\$ 911 .^{8}$

Finally, we define an individual has having long term care insurance in the 1995 AHEAD if they answer a question about this coverage affirmatively. ${ }^{9}$ About 10 percent have long term care insurance. The corresponding risk occurrence measure is whether the individual goes into a nursing home between 1995 and 2002; about one-quarter of the sample does.

\subsection{Behavior measures}

\footnotetext{
${ }^{5}$ Holding an annuity is defined as an affirmative answer to a question in the survey asking if he has annuity income from a source other than Social Security or a Defined Benefit Pension. Because our sample for this analysis consists of those aged 65 or older, we do not believe that many will start receiving annuity payments at a later date.

${ }^{6}$ During the period of time covered by our data, some Medigap policies also provided prescription drug coverage.

7 The question asks, "Not counting long-term care insurance or [Medicare, Medicaid, government health insurance] do you have any health insurance that pays any part of hospital or doctor bills? (Sometimes this is called a Medi-Gap policy).”

8 The HRS reports the number of doctor and hospital visits an individual experienced since the previous interview (approximately 2 years). To translate these numbers into an estimate of expenditures not covered by Medicare we assume an uncovered (by Medicare) expenditure of \$100 for the first and second doctor visit in a two year period (i.e. the annual Medicare part B deductible in 1995) and \$20 for each additional visit (i.e. the 20\% part B coinsurance). We also assume a cost of $\$ 716$ for each hospital visit (ie.. the Medicare Part A deductible in 1995). No attempt is made to account for hospital stays beyond 60 days at which a copayment kicks in; this is a very rare event in our sample. We do not attempt to measure other potentially covered expenses such as prescription drugs. We do not also impute total spending for acute health insurance as it would require more detailed information than is available about medical care utilization.

${ }^{9}$ The question in the 1995 wave of AHEAD is “Aside from the government programs, do you now have any insurance which specifically pays any part of long-term care, such as, personal or medical care in the home or in a nursing home?
} 
We have five behavior measures that we observe in both the HRS and AHEAD samples. Three are measures of risky behavior: (1) whether the individual currently smokes (2) whether the individual has a drinking problem (defined as three or more drinks per day), and (3) the mortality rate per 100,000 employees in the individual's industry-occupation cell (for the HRS) or occupation cell (for the AHEAD). ${ }^{10}$ On average, in our 1992 sample of near-elderly, 27 percent of people smoke, 5 percent have a drinking problem, and the average mortality risk by industry-occupation cell is 4 fatalities per 100,000 employees. Smoking rates are lower in the elderly (7.6 percent of the sample), reflecting the strong difference in mortality by smoking status at older ages.

We also construct two measures of active steps individuals can take to reduce mortality and healthy risk: (1) the fraction of gender-appropriate preventive health activity undertaken, ${ }^{11}$ and (2) whether the individual reports always wearing a seat belt. For our 1995 AHEAD sample, we observe these measures contemporaneously in 1995. Unfortunately, for the 1992 HRS sample, these measures are first available in 1996. Our analysis of the preventive health behaviors and seat belt use for the 1992 insurance variables therefore suffers from potential sample selection bias; to observe this behavior the individual must survive until 1996. On average in the 1992 HRS sample, individuals undertake 60 percent of gender-appropriate health activities, and 80 report always wearing a seat belt. For the 1995 AHEAD sample, the figures are 65 percent and 83 percent.

We examine both the simple, unconditional bivariate relationship between each of these behaviors and either insurance coverage or risk occurrence. We also report results in which we control for covariates (X) designed to capture the risk classification used by insurers. Conditioning on the characteristics used in pricing insurance is crucial for papers testing the predictions of standard adverse selection models, as these

\footnotetext{
10 The mortality rates are from Viscusi (2003), who uses data from the U.S. Bureau of Labor Statistics Census of Fatal Occupational Injuries. We define industry-occupation cells (or occupation alone) based on current job (if any), including self employment. If the individual is not currently employed we use the most recent job or, if this variable is missing, the most significant prior attachment. If the individual has never held a job (or all of these measures are missing) the measure of industry-occupation mortality risk is missing.

${ }^{11}$ These activities are: whether the individual had a flu shot; had a blood test for cholesterol; checked her breasts for lumps monthly; had a mammogram or breast x-ray; had a Pap smear; had a prostate screen. See Finkelstein and McGarry (2006) for a study using these variables in this manner.
} 
predictions are about how people behave conditional on the menu of contracts they face (Chiappori and Salanie, 2000). However, when examining the influence of preferences on insurance demand and risk type, the unconditional relationships may be of greater interest, since we are primarily interested in how preferences mediate the insurance - risk occurrence relationship through their impact on both risky behavior and insurance valuation. We thus emphasize the unconditional relationships although we present the conditional relationships as well for completeness and for comparability with the existing literature. Appendix A describes the risk classification controls in detail.

\section{Results}

\subsection{Insurance demand and risky behavior}

Table 2 examines the relationship between the various behaviors and each of the five insurance products. It reports the results from estimating equation (1) both with (even columns) and without (odd columns) conditioning variables. The results are remarkably consistent across behavior measures and across insurance types. Individuals who engage in more risky behavior are systematically less likely to have each type of insurance; the results are not sensitive to whether or not we control for risk classification.

The relationships between risky behavior and insurance coverage are particularly strong for preventive health activity and seat belt use - which are positively and statistically significantly correlated with having each insurance product - and for the mortality rate of the individual's industry-occupation cell - which is negatively and statistically significantly correlated with each type of insurance coverage. Similar patterns are present - but are somewhat less robust - for smoking and drinking. Smokers are statistically significantly less likely to have life insurance, annuities, Medigap, and private health insurance, but there is no discernable relationship between smoking and long-term care insurance. Individuals who drink are almost always less likely to have each type of insurance, but the results are rarely statistically significant. ${ }^{12}$

Our interpretation of these findings is that more risk averse individuals both invest in more risk reducing (less risky) behavior and value insurance more. Consistent with this, we find suggestive evidence of a

\footnotetext{
${ }^{12}$ Both smoking and drinking are thought to be addictive and altering one's behavior along these dimensions is likely to be more difficult that deciding to wear a seat belt or get a flu shot. They may therefore be less representative of current preferences than other variables.
} 
negative relationship between risk aversion and risky behavior. As a proxy for risk aversion, we use the respondents' answers to questions concerning their willingness to engage in various hypothetical income gambles. ${ }^{13}$ This variable is available only for the 1992 HRS sample. Based on the answers, we form four ordinal categorical variables of decreasing risk aversion and examine their relationship with risky behavior. About 65 percent of the sample falls in the most risk averse category; the remainder are roughly evenly split across the other three risk aversion categories.

Table 3 reports our results concerning the relationship between various risky behaviors and these ordinal measures of risk aversion. Overall, the evidence suggests that those who are in the least risk averse category are more likely to engage in various risky behaviors (or less likely to engage in risk reducing behaviors) than those in the most risk averse category, although the differences are statistically significant only for the risky behaviors measures, and not for the risk reducing behaviors. ${ }^{14}$

\subsection{Risky behavior and risk occurrence}

Table 4 examines the relationship between risky behavior and risky outcomes, equation (2) above. As in Table 2, we report both unconditional and conditional estimates, and focus on the unconditional estimates.

The first two panels examine the relationship between more risky (less risk reducing) behaviors and mortality in the life insurance sample (Panel A) and the annuity sample (Panel B). The results show a broad pattern that more risky behavior (smoking, drinking, and higher mortality occupations and industries) is associated with (usually statistically significantly) higher mortality, and that investment in risk reducing behavior (preventive health activity or seat belt wearing) is associated with (usually statistically significant) lower mortality. These findings suggest that preferences for insurance - and their differential relationship with risk in life insurance and annuities - may be able to explain the different patterns observed in these two

\footnotetext{
${ }^{13}$ The survey questions as respondents if they would be willing to trade a good job with a steady income equal to their current family income for a new job with a "50-50 chance it will double your (family) income and a 50-50 chance that it will cut your (family) income by a third.” A second question increases or decreases the possible gain / loss in income depending on the response to the initial question. These responses can be used to group people into four risk-tolerance categories.

${ }^{14}$ Using additional assumptions (e.g. that the utility function exhibits constant relative risk aversion) and data, Barksy et al. (1997) construct measures of average risk tolerance for the four categories and find even more pronounced relationships between risk aversion and risky behaviors than what we report using the ordinal measures.
} 
markets of the relative risk profile of those with more insurance. Individuals who engage in less risky (more risk reducing) behavior demand both more life insurance and more annuities (Table 2) and have higher mortality (Table 4). From the insurance company perspective, this makes them lower expected cost for life insurance (less likely to die and make a claim), thus offsetting the standard adverse selection pattern, but higher expected cost for annuities (less likely to die and stop making claims), thus reinforcing the standard adverse selection pattern.

Life insurance is one of the largest private insurance markets in the world. Previous work has demonstrated that the market does not exhibit higher ownership rates among higher risk individuals, as standard adverse selection or moral hazard models would predict (Cawley and Philipson 1999, McCarthy and Mitchell 2003). Nor does variability in financial exposure explain ownership patterns (Bernheim et al. 2003a 2003b). Our empirical results suggest that heterogeneity in risk tolerance may be able to provide a sensible explanation for the observed patterns of coverage. Specifically, we find that individuals who engage in more risky behavior are both higher mortality risk and less likely to purchase insurance.

Panel C examines at the relationship between behaviors and subsequent use of nursing homes. Although there is no systematic relationship between risky behaviors and nursing home use, we find that individuals who engage in more risk reducing behavior - be it preventive health activity or seat belt use - are less likely to go into a nursing home between 1995 and 2002. This finding was previously documented by Finkelstein and McGarry (2006) over a different time period, who argue that the link between more risk reducing behavior, demand for insurance, and expected claims may explain why the insured do not, on average, have higher nursing home use than the uninsured.

Panel D looks at the relationship between the various behaviors and the risk Medigap insures of medical expenditures not covered by Medicare. The results are mixed; some risky behaviors are correlated with lower medical expenditures while others are correlated with higher medical expenditures; the same ambiguity is present for the risk reducing behaviors. The results are similar if we use the number of doctor visits or the number of nights spent in a hospital as the dependent variable (not shown). Some of these behaviors therefore act to offset the standard asymmetric information effects, while others serve to reinforce 
them. Fang et al. (2006) have documented additional sources of advantageous selection in Medigap. In particular, those with higher cognitive ability are both more likely to purchase Medigap and have lower expected claims.

Finally, Panel E looks at the relationship between the various behaviors and whether the individual has any hospital use, which is an important component of the costs that acute private health insurance would cover. The results are similar if we use the number of doctor visits or the number of nights spent in a hospital as the dependent variable (not shown). Again the results are mixed; some risky behaviors are correlated with lower utilization while others are correlated with higher utilization.

\section{Interpretation and Conclusions}

Our analysis yields two main findings. First, in all five markets, we find that individuals who engage in what are commonly thought of as risky behaviors (smoking, drinking, or prior employment in jobs with higher mortality rates) or who do not take measures to thought to reduce risk (preventive health activities or wearing of a seat belt) are systematically less likely to hold each of these insurance products. ${ }^{15}$ Second, we find that these same individuals tend to have higher expected claims for life insurance and long term care insurance, but lower expected claims for annuities; for Medigap and acute health insurance, there is no systematic relationship between the behavior measures and expected claims.

These results can help to explain the puzzle of insurance we started with: why is adverse selection not more common? In annuity markets, there is clear evidence of adverse selection: people who live longer are more likely to buy insurance. The standard adverse selection model is one explanation for this, but so is variation in risk tolerance; people who have less risky behaviors live longer and are more likely to buy annuities. In life insurance, our results suggest that differential risk tolerance can help explain why people with lower mortality rates have more insurance. Similarly, in the case of long-term care insurance, people who use more preventive care or are more likely to wear seat belts buy insurance more readily but also stay

\footnotetext{
${ }^{15}$ Here we use the term "risk" to denote the chance of what is generally considered to be an undesirable event for the individual (namely, worse health or death). Of course, in the context of insurance purchasing, the "risk" depends on what is being insured. For example, from the insurance company's perspective a high mortality individual will be "high risk" as a life insurance consumer but "low risk" as an annuity buyer.
} 
out of nursing homes. For acute health insurance, the lack of any systematic offsetting effect of risk tolerance may explain why the preponderance of studies have found that this market is, on net, adversely selected. In the case of Medigap, other sources of advantageous selection than risk tolerance appear to be necessary to understand why this market is on net advantageously selected; indeed, Fang, Keane and Silverman (2006) have documented that those with higher cognitive ability are both more likely to purchase Medigap and have lower expected claims.

Overall, our findings suggest that preferences for insurance - and their impact on risk occurrence and insurance purchase - may help explain the different patterns of selection observed in different insurance markets. These preference effects thus provide a potential unifying explanation for the differential patterns in insurance coverage across different markets.

Our results have a number of implications. Most importantly, they suggest that in considering the nature of market inefficiencies created by private information in insurance markets, the possibility of over-insurance from advantageous selection should be considered in addition to the under-insurance concern of classic, unidimensional adverse selection models. The implications of this for welfare have received some attention (de Meza and Webb 2001) and are a fruitful subject for future research. 


\section{References}

Barsky, Robert, Thomas Juster, Miles Kimball and Matthew Shapiro. 1997. "Preference parameters and behavioral heterogeneity: An experimental approach in the health and retirement study." Quarterly Journal of Economics 112(2): 537-579.

Bernheim, Douglas, Lorenzo Forni, Jagadeesh Gokhale, and Laurence Kotlikoff. 2003a. "The Mismatch Between Life Insurance and Financial Vulnerabilities: Evidence from the Health and Retirement Survey," American Economic Review 93(1), March: 354-365.

Bernheim, Douglas, Katherine Carman, Jagadeesh Gokhale, and Laurence Kotlikoff. 2003b. “Are Life

Insurance Holdings Related to Financial Vulnerabilities?” Economic Inquiry 41(4), October: 531-54.

Cardon, James and Igal Hendel. 2001. "Asymmetric Information in Health Insurance: Evidence from the National Medical Expenditure Survey.” RAND Journal of Economics 32, 408-427.

Cawley, John and Tomas Philipson. 1999. "An empirical examination of information barriers to trade in insurance.” American Economic Review Vol 89, no 4 pp.827-846.

Chiappori, Pierre-Andre and Bernard Salanie. 2000. "Testing for Asymmetric Information in Insurance Markets." Journal of Political Economy, 108 (1), pp. 56-78.

Chiappori, Pierre-Andre, Bruno Jullien, Bernard Salanie, and Francois Salanie. 2006. "Asymmetric

Information in Insurance: General Testable Implications." Rand Journal of Economics. 37 (4)

Cohen, Alma. 2005. “Asymmetric Information and Learning in the Automobile Insurance

Market." Review of Economics and Statistics 87: 197-207.

Cohen Alma and Liran Einav. 2007. "Estimating risk preferences from deductible choice." American

Economic Review, 97 (3) : 745-788.

Cutler, David and Richard Zeckhauser. 2000. "The Anatomy of Health Insurance" in A. Culyer and J.

Newhouse, eds. Handbook of Health Economics, Volume IA, Amsterdam: Elsevier.

Dionne, Georges and Louis Eeckhoudt. "Self-Insurance, Self-Protection, and Increased Risk Aversion.”

Economic Letters 1985, 17, pp. 39-42.

Davidoff, Thomas and Gerd Welke. 2005. "Selection and moral hazard in the reverse mortgage market." Unpublished mimeo.

de Meza, David and Webb, David C. 2001. "Advantageous selection in insurance markets." Rand

Journal of Economics, 32 (2), pp. 249-262.

Ettner, Susan, 1997. “Adverse Selection and the Purchase of Medigap Insurance by the Elderly,” Journal of Health Economics, 16 (5) : 499-624.

Fang, Hamming, Michael Keane, and Daniel Silverman, 2006. "Sources of Advantageous

Selection:Evidence from the Meidgap Insurance Market. NBER working paper 12289.

Finkelstein, Amy and Kathleen McGarry. 2006. "Private information and its effect on market

equilibrium: new evidence from long-term care insurance." American Economic Review 96(4): 938 - 958.

Finkelstein, Amy and James Poterba. 2002. "Selection Effects in the Market for Individual Annuities:

New Evidence from the United Kingdom." Economic Journal, 112 (476), pp. 28-50.

Finkelstein, Amy and James Poterba. 2004. "Adverse Selection in Insurance Markets: Policyholder

Evidence from the U.K. Annuity Market." Journal of Political Economy, 112(1), pp. 193-208.

Finkelstein, Amy and James Poterba. 2006. "Testing for adverse selection with 'unused observables'.” Unpublished mimeo.

Hurd, Michael and Kathleen McGarry 1997. "Medical Insurance and the Use of Health Care Services by the Elderly,” Journal of Health Economics, 16 (2) : 129-154.

Jullien Bruno, Bernard Salanie and Francois Salanie. 1999. "Should More Risk-Averse Agents Exert More Effort?” The Geneva Papers on Risk and Insurance Theory, 24, pp. 19-28.

Jullien, Bruno, Bernard Salanie, and Francois Salanie. 2002. "Screening risk-averse agents under moral hazard." Unpublished mimeo.

McCarthy, David and Olivia Mitchell. 2003. "International Adverse Selection in Life Insurance and Annuities.” NBER Working Paper 9975.

Mehta, Kala M., Kristine Yaffe, Kenneth Langa, Laura Sands, Mary Whooley and Kenneth Covinsky, 
2002. Additive Effects of cognitive Function and Depressive Symptoms of Mortality in Older Community Living Adults,” University of Michigan, unpublished paper.

Mitchell, Olivia S., James M. Poterba, Mark Warshawsky, and Jeffrey R. Brown. 1999. "New Evidence on the Money's Worth of Individual Annuities." American Economic Review, 89, 1299-1318.

Rothschild, Michael and Joseph E. Stiglitz. 1976. "Equilibrium in Competitive Insurance Markets: An Essay on the Economics of Imperfect Information," Quarterly Journal of Economics 90, 630-649.

Viscusi, W. Kip. 2003. “The Value of Life: Estimates with Risks by Occupation and Industry,” John M. Olin Center for Law, Economics and Business, Discussion Paper no. 422, May.. 
Table 1: Summary Statistics

\begin{tabular}{|c|c|c|}
\hline & \multicolumn{2}{|c|}{ Sample } \\
\hline Variable & 1992 HRS & 1995 AHEAD \\
\hline Average Age & $56.0(3.2)$ & $79.0(4.8)$ \\
\hline$\%$ Male & 47.6 & 39.8 \\
\hline \% Married & 76.8 & 52.5 \\
\hline \multicolumn{3}{|l|}{ Behaviors } \\
\hline Smoker & 26.9 & 7.6 \\
\hline Drinking problem & 5.3 & 3.0 \\
\hline $\begin{array}{l}\text { Mortality risk of industry- } \\
\text { occupation cell }\end{array}$ & $3.98(5.50)$ & 3.79 (4.13) \\
\hline $\begin{array}{l}\text { Percent of sex-appropriate } \\
\text { preventative measures } \\
\text { undertaken }\end{array}$ & 60.0 & 64.9 \\
\hline Fraction always using seatbelt & 79.6 & 83.0 \\
\hline \multicolumn{3}{|l|}{ Insurance } \\
\hline \% with Term Life insurance & 50.7 & --- \\
\hline \multicolumn{3}{|l|}{ Insurance } \\
\hline \% with Medigap & ---- & 69.5 \\
\hline \multicolumn{3}{|l|}{ Insurance } \\
\hline \% with Annuity & ---- & 7.5 \\
\hline $\mathrm{N}$ & 11,913 & 7,183 \\
\hline \multicolumn{3}{|c|}{$\begin{array}{l}\text { Number of observations varies across variables due to missing values. The number of observations is unweighted. } \\
\text { Individuals specific weights for } 1992 \text { and } 1995 \text { are used. The measure of any health insurance excludes those who are } \\
\text { covered by a government programs (e.g. Medicare, Medicaid, CHAMPUS, CHAMPVA). Medigap includes any health } \\
\text { insurance policy that supplements Medicare, it may be provided through a current or former employer (or spouse's }\end{array}$} \\
\hline
\end{tabular}


Table 2: The relationship between risky (or risk reducing) behavior and insurance coverage.

\begin{tabular}{|c|c|c|c|c|c|c|c|c|c|c|}
\hline & (1) & $(2)$ & (3) & (4) & (5) & $(6)$ & $(7)$ & $(8)$ & (9) & $(10)$ \\
\hline RHS var & \multicolumn{2}{|c|}{ Smoker } & \multicolumn{2}{|c|}{ Drinking problem } & \multicolumn{2}{|c|}{ Mortality Risk in } & \multicolumn{2}{|c|}{ Preventative Health } & \multicolumn{2}{|c|}{ Always wear seat belt } \\
\hline \multicolumn{11}{|c|}{ Panel A: Dependent Variable Is Term Life Insurance Coverage in $1992($ mean = 0.50) } \\
\hline \multirow[t]{2}{*}{ Coeff } & $-0.034 * * *$ & $-0.021 *$ & -0.017 & $-0.037 *$ & $-0.002 *$ & $-0.003^{* * *}$ & $0.115^{* * *}$ & $0.126 * * *$ & $0.063 * * *$ & $0.072 * * *$ \\
\hline & $(.010)$ & $(.011)$ & $(.021)$ & $(.022)$ & $(.001)$ & $(.001)$ & $(.016)$ & $(.017)$ & $(.013)$ & $(.013)$ \\
\hline Controls & No & Yes & No & Yes & No & Yes & No & Yes & No & Yes \\
\hline $\mathrm{N}$ & 11453 & 10385 & 11453 & 10385 & 10556 & 9582 & 9773 & 8952 & 9805 & 8983 \\
\hline \multicolumn{11}{|c|}{ Panel B: Dependent Variable is Annuity Income in 1995 (mean = 0.07) } \\
\hline \multirow[t]{2}{*}{ Coeff } & $-0.027 * * *$ & $-0.030 * * *$ & -0.013 & -0.018 & $-0.003 * * *$ & $-0.004 * * *$ & $0.053 * * *$ & $0.052 * * *$ & $0.030 * * *$ & $0.029 * * *$ \\
\hline & (.009) & $(.009)$ & $(.016)$ & $(.017)$ & $(.001)$ & $(.001)$ & $(.010)$ & $(.010)$ & $(.007)$ & $(.007)$ \\
\hline Controls & No & Yes & No & Yes & No & Yes & No & Yes & No & Yes \\
\hline $\mathrm{N}$ & 6420 & 6371 & 6393 & 6345 & 4878 & 4835 & 6251 & 6203 & 6408 & 6359 \\
\hline \multicolumn{11}{|c|}{ Panel C: Dependent Variable is Long-term Care Coverage in 1995 (mean=0.10) } \\
\hline \multirow[t]{2}{*}{ Coeff } & 0.007 & 0.007 & 0.016 & -0.007 & $-0.002 * *$ & $-0.003 * *$ & $0.082 * * *$ & $0.073 * * *$ & $0.037 * * *$ & $0.041 * * *$ \\
\hline & $(.014)$ & $(.015)$ & $(.023)$ & $(.025)$ & $(.001)$ & $(.001)$ & $(.011)$ & $(.014)$ & $(.009)$ & $(.010)$ \\
\hline Controls & No & Yes & No & Yes & No & Yes & No & Yes & No & Yes \\
\hline $\mathrm{N}$ & 6401 & 5396 & 6376 & 5377 & 4845 & 4145 & 6233 & 5312 & 6390 & 5394 \\
\hline \multicolumn{11}{|c|}{ Panel D: Dependent Variable is Medigap Coverage in 1995 (mean=0.65) } \\
\hline \multirow[t]{2}{*}{ Coeff } & $-0.083 * * *$ & $-0.084 * * *$ & -0.022 & -0.022 & $-0.016 * * *$ & $-0.016 * * *$ & $0.187^{* * *}$ & $0.189 * * *$ & $0.058 * * *$ & $0.058 * * *$ \\
\hline & $(.022)$ & $(.022)$ & $(.035)$ & $(.035)$ & $(.002)$ & $(.002)$ & $(.020)$ & $(.020)$ & $(.016)$ & $(.016)$ \\
\hline Controls & No & Yes & No & Yes & No & Yes & No & Yes & No & Yes \\
\hline $\mathrm{N}$ & 6383 & 6383 & 6357 & 6357 & 4852 & 4852 & 6218 & 6218 & 6373 & 6373 \\
\hline \multicolumn{11}{|c|}{ Panel E: Dependent Variable is Any (non-governmental) health insurance coverage in 1992 (mean = 0.84$)$} \\
\hline Coeff & $\begin{array}{l}-0.084^{* * *} \\
(.009)\end{array}$ & NA & $\begin{array}{l}-0.046^{* * * *} \\
(.017)\end{array}$ & NA & $\begin{array}{l}-0.005^{* * * *} \\
(.001)\end{array}$ & NA & $\begin{array}{l}0.220 * * * \\
(.013)\end{array}$ & NA & $\begin{array}{l}0.058 * * * \\
(.010)\end{array}$ & NA \\
\hline Control & No & & No & & No & & No & & No & \\
\hline $\mathrm{N}$ & 10,945 & & 10,945 & & 10,207 & & 9,411 & & 9,448 & \\
\hline
\end{tabular}

Note: Table reports results from OLS regressions. Dependent variable is given in panel headings. First row gives coefficient on right hand side variable listed at the top of the column. All right hand side variables are measured in the year insurance is measured (1992 or 1995 as indicated) except for preventive health activity and seat belt use for 1992 insurance coverage where they are measured in 1996. Additional controls consist of variables used by the insurance company to assess risk. They vary by insurance market. For life insurance and long-term care insurance we use an array of health measures, age, smoking status, and sex. For annuities we use age, spouse's age and sex. For Medigap coverage we use age. See Appendix A for a complete listing of control variables. Heteroskedasticity-robust standard errors are in parentheses. $* * *, * *, *$ denotes statistical significance at the 1 percent, 5 percent, and 10 percent levels respectively 
Table 3: The relationship between risk aversion and risky behavior

\begin{tabular}{|c|c|c|c|c|c|c|c|c|c|c|}
\hline & \multicolumn{2}{|c|}{$\begin{array}{l}\text { Indicator for Smoker } \\
\text { (1992) }\end{array}$} & \multicolumn{2}{|c|}{$\begin{array}{c}\text { Indicator for } \\
\text { Drinking Problem (1992) }\end{array}$} & \multicolumn{2}{|c|}{$\begin{array}{l}\text { Mortality Risk in } \\
\text { Industry-Occupation Cell } \\
(1992)\end{array}$} & \multicolumn{2}{|c|}{$\begin{array}{c}\text { Preventive Health } \\
\text { Activity (1996) }\end{array}$} & \multicolumn{2}{|c|}{$\begin{array}{c}\text { Always Wear Seat } \\
\text { Belt (1996) }\end{array}$} \\
\hline & (1) & (2) & (3) & (4) & (5) & (6) & (7) & (8) & (9) & (19) \\
\hline $\begin{array}{l}\text { Most risk } \\
\text { averse }\end{array}$ & -- & -- & -- & -- & -- & -- & -- & -- & -- & -- \\
\hline $\begin{array}{l}\text { Second } \\
\text { most risk } \\
\text { averse }\end{array}$ & $\begin{array}{l}0.011 \\
(0.014)\end{array}$ & $\begin{array}{l}0.003 \\
(0.013)\end{array}$ & $\begin{array}{l}0.004 \\
(0.007)\end{array}$ & $\begin{array}{l}0.004 \\
(0.006)\end{array}$ & $\begin{array}{l}-0.262^{*} \\
(0.157)\end{array}$ & $\begin{array}{l}-0.113 \\
(0.151)\end{array}$ & $\begin{array}{l}0.005 \\
(0.010)\end{array}$ & $\begin{array}{l}0.002 \\
(0.010)\end{array}$ & $\begin{array}{l}0.009 \\
(0.013)\end{array}$ & $\begin{array}{l}-0.001 \\
(0.013)\end{array}$ \\
\hline $\begin{array}{l}\text { Third most } \\
\text { risk averse }\end{array}$ & $\begin{array}{l}-0.006 \\
(0.014)\end{array}$ & $\begin{array}{l}-0.012 \\
(0.014)\end{array}$ & $\begin{array}{l}-0.004 \\
(0.006)\end{array}$ & $\begin{array}{l}-0.0099^{*} \\
(0.006)\end{array}$ & $\begin{array}{l}0.141 \\
(0.178)\end{array}$ & $\begin{array}{l}0.102 \\
(0.171)\end{array}$ & $\begin{array}{l}-0.002 \\
(0.010)\end{array}$ & $\begin{array}{l}-0.003 \\
(0.011)\end{array}$ & $\begin{array}{l}0.001 \\
(0.013)\end{array}$ & $\begin{array}{l}0.001 \\
(0.013)\end{array}$ \\
\hline $\begin{array}{l}\text { Least risk } \\
\text { averse }\end{array}$ & $\begin{array}{l}0.048^{* * *} \\
(0.014)\end{array}$ & $\begin{array}{l}0.041^{* * *} \\
(0.013)\end{array}$ & $\begin{array}{l}0.026 * * * \\
(0.007)\end{array}$ & $\begin{array}{l}0.023 * * * \\
(0.008)\end{array}$ & $\begin{array}{l}0.503^{* * *} \\
(0.185)\end{array}$ & $\begin{array}{l}0.249 \\
(0.177)\end{array}$ & $\begin{array}{l}0.017^{*} \\
(.010)\end{array}$ & $\begin{array}{l}-0.012 \\
(0.010)\end{array}$ & $\begin{array}{l}-0.018 \\
(0.013)\end{array}$ & $\begin{array}{l}-0.014 \\
(0.013)\end{array}$ \\
\hline $\begin{array}{l}\text { Add'l } \\
\text { controls }\end{array}$ & No & Yes & No & Yes & No & Yes & No & Yes & No & Yes \\
\hline $\mathrm{N}$ & 11,040 & 10,564 & 11,040 & 10,564 & 10193 & 9,755 & 9,481 & 9,087 & 9,512 & 9,119 \\
\hline
\end{tabular}

Note: Table reports results from OLS regressions. Dependent variable is given in column headings. Risk aversion is an ordinal measure based on willingness to accept various hypothetical gambles; see text and Barsky et al. (1997) for more details. Additional controls consist of variables used by the insurance company to assess risk. They vary by insurance market (see endnote to table 2 ). Heteroskedasticity-robust standard errors are in parentheses. $* * *, * *, *$ denotes statistical significance at the 1 percent, 5 percent, and 10 percent levels respectively. 
Table 4: The relationship between risky (or risk reducing) behavior and risky outcome

\begin{tabular}{|c|c|c|c|c|c|c|c|c|c|c|}
\hline \multirow[b]{2}{*}{ RHS var } & \multirow{2}{*}{\multicolumn{2}{|c|}{ Smoker }} & (3) & (4) & $(5)$ & (6) & (7) & $(8)$ & $(9)$ & $(10)$ \\
\hline & & & \multicolumn{2}{|c|}{ Drinking problem } & \multicolumn{2}{|c|}{$\begin{array}{c}\text { Mortality Risk in } \\
\text { Industry-Occupation } \\
\text { cell }\end{array}$} & \multicolumn{2}{|c|}{$\begin{array}{l}\text { Preventative Health } \\
\text { Activity }\end{array}$} & \multicolumn{2}{|c|}{ Always wear seat belt } \\
\hline \multicolumn{11}{|c|}{ Panel A: Dependent Variable Is Mortality 1992 to $2002($ mean = 0.13) } \\
\hline Coeff & $\begin{array}{l}0.110 * * * \\
(.008)\end{array}$ & $\begin{array}{l}0.089 * * * \\
(.008)\end{array}$ & $\begin{array}{l}0.083^{* * *} \\
(.017)\end{array}$ & $\begin{array}{l}0.029 * \\
(.016)\end{array}$ & $\begin{array}{l}0.004 * * * \\
(.001)\end{array}$ & $\begin{array}{l}0.001 \\
(.001)\end{array}$ & $\begin{array}{l}-0.011 \\
(.010)\end{array}$ & $\begin{array}{l}-0.005 \\
(.010)\end{array}$ & $\begin{array}{l}-0.048 * * * \\
(.008)\end{array}$ & $\begin{array}{l}-0.018 * * \\
(.008)\end{array}$ \\
\hline Controls & No & Yes & No & Yes & No & Yes & No & Yes & No & Yes \\
\hline $\mathrm{N}$ & 11191 & 10141 & 11191 & 10141 & 10295 & 9348 & 10085 & 8988 & 10123 & 9023 \\
\hline \multicolumn{11}{|c|}{ Panel B: Dependent Variable is Mortality 1995 to $2002($ mean $=0.38)$} \\
\hline Coeff & $\begin{array}{l}0.098^{* * *} \\
(.022)\end{array}$ & $\begin{array}{l}0.102^{* * *} \\
(.022)\end{array}$ & $\begin{array}{l}0.021 \\
(.035)\end{array}$ & $\begin{array}{l}-0.013 \\
(.036)\end{array}$ & $\begin{array}{l}0.007 * * * \\
(.002)\end{array}$ & $\begin{array}{l}0.002 \\
(.002)\end{array}$ & $\begin{array}{l}-0.148^{* * *} \\
(.020)\end{array}$ & $\begin{array}{l}-0.196^{* * * *} \\
(.020)\end{array}$ & $\begin{array}{l}-0.104^{* * *} \\
(.016)\end{array}$ & $\begin{array}{l}-0.093^{* * *} \\
(.016)\end{array}$ \\
\hline Controls & No & Yes & No & Yes & No & Yes & No & Yes & No & Yes \\
\hline $\mathrm{N}$ & 6455 & 6403 & 6428 & 6377 & 5681 & 5072 & 6285 & 6234 & 6432 & 6382 \\
\hline \multicolumn{11}{|c|}{ Panel C: Dependent Variable is 0/1 any nursing home use 1995 to 2002 (mean=0.24) } \\
\hline Coeff & $\begin{array}{l}-0.011 \\
(.019)\end{array}$ & $\begin{array}{l}-0.021 \\
(.020)\end{array}$ & $\begin{array}{l}-0.030 \\
(.029)\end{array}$ & $\begin{array}{l}.003 \\
(.031)\end{array}$ & $\begin{array}{l}-0.001 \\
(.001)\end{array}$ & $\begin{array}{l}-0.002 \\
(.002)\end{array}$ & $\begin{array}{l}-0.127^{* * *} \\
(.018)\end{array}$ & $\begin{array}{l}-0.080^{* * *} \\
(.020)\end{array}$ & $\begin{array}{l}-0.053^{* * * *} \\
(.015)\end{array}$ & $\begin{array}{l}-0.042 * * * \\
(.016)\end{array}$ \\
\hline Controls & No & Yes & No & Yes & No & Yes & No & Yes & No & Yes \\
\hline $\mathrm{N}$ & 6217 & 5307 & 6193 & 5288 & 4849 & 4070 & 6080 & 5227 & 6203 & 5306 \\
\hline \multicolumn{11}{|c|}{ Panel D: Dependent variable is Medical Costs in 1995 that could be covered by Medigap $(\text { mean }=911)^{\dagger}$} \\
\hline Coeff & $\begin{array}{l}-103.1^{* * * *} \\
(40.2)\end{array}$ & $\begin{array}{l}-98.3 * * \\
(40.5)\end{array}$ & $\begin{array}{l}-112.3^{* *} \\
(54.5)\end{array}$ & $\begin{array}{l}-111.7^{* *} \\
(54.6)\end{array}$ & $\begin{array}{l}9.3^{* * *} \\
(3.6)\end{array}$ & $\begin{array}{l}9.2^{* * *} \\
(3.6)\end{array}$ & $\begin{array}{l}305.1 * * * \\
(36.6)\end{array}$ & $\begin{array}{l}301.9 * * * \\
(36.6)\end{array}$ & $\begin{array}{l}-99.4^{*} \\
(59.9)\end{array}$ & $\begin{array}{l}-99.5^{*} \\
(60.0)\end{array}$ \\
\hline Controls & No & Yes & No & Yes & No & Yes & No & Yes & No & Yes \\
\hline $\mathrm{N}$ & 6317 & 6317 & 6294 & 6294 & 4782 & 4782 & 6168 & 6168 & 6307 & 6307 \\
\hline \multicolumn{11}{|c|}{ Panel E Dependent variables is 0/1 entered a hospital in the preceding two years from $1992($ mean= 0.091$)$} \\
\hline Coeff & $\begin{array}{l}-0.006 \\
(.006)\end{array}$ & NA & $\begin{array}{l}0.010 \\
(.013)\end{array}$ & NA & $\begin{array}{l}0.002 * * * \\
(.001)\end{array}$ & NA & $\begin{array}{l}0.060 * * * \\
(.009)\end{array}$ & NA & $\begin{array}{l}-0.021 * * * \\
(.008)\end{array}$ & NA \\
\hline Controls & No & & No & & No & & No & & No & \\
\hline
\end{tabular}

Note: Table reports results from OLS regressions. Dependent variables are given in panel headings. First row in each panel gives coefficient on right hand side variable listed at the top of the column. All right hand side variables are measured in 1992 for Panel A and E except for preventive health activity and seat belt use which are measured in 1996; all right hand side variables in Panels C, D and E are measured in 1995. Additional controls consist of variables used by the insurance company to assess risk. They vary by insurance market. For life insurance we use an array of health measures, age, smoking status, and sex. For annuities we use age, spouse's age and sex. See Appendix A for further information. Heteroskedasticity-robust standard errors are in parentheses. ${ }^{* * *}, * *, *$ denotes statistical significance at the 1 percent, 5 percent, and 10 percent levels respectively.

${ }^{\dagger}$ costs not covered my medicare are proxied by $\$ 100$ for the first and second doctor visit in a two year period and $\$ 20$ for each additional visit $+\$ 716$ (medicare deductible in 1995) for each hospital visit. No attempt is made to account for stays beyond 60 days at which the copayment kicks in. (\$179 for days $61-90) 8$ people have just one stay of more than 60 days, 48 people have more than one stay and a TOTAL of more than 60 days. 


\section{Appendix A: Definitions of risk classification controls}

In this appendix we provide a detailed description of the controls for risk that we use in each insurance market. We base our decisions of which factors to include by inspection of the information insurers collect and use in pricing premiums. We discuss, in turn, our controls in each market. We also verified that our results are not sensitive to the addition or subtraction of many variables.

Life insurance classification risk: In the life insurance market the degree of underwriting depends on the size of the policy and the age of the applicant. In cases in which there is underwriting, the insured often undergoes an exam and / or receives a blood test. We include dummy variables indicating low (below 20) and high (above 30) body mass index. We also include indicators of difficulty with a series of activities of daily living (walking, getting in and out of bed, bathing, dressing and eating and the total number of such limitations), high blood pressure, diabetes or high blood sugar, whether the individual takes medication for diabetes, had cancer (other than skin cancer), lung disease, heart disease or a heart attack, takes medication for heart disease, had a stroke, psychiatric problems, arthritis, asthma, kidney or bladder problems, high cholesterol, or a bone fracture. As a measure of cognitive function we include the number of words recalled immediately after having a list read and the number recalled after delay. We include indicators of whether the individual is married, smokes, dummy variables for individual ages, gender, male, number of limitations with respect to activities of daily living and an indicator of their depressive state based on CESD scores as recommended by Mehta et al. (2002).

Acute health insurance risk classification: Because health insurance is obtained primarily through an employer, and there is no underwriting for employer provided coverage, we do not conduct any analysis using control variables.

Annuity classification risk: In the United States, insurers providing annuities condition solely on age and sex. We use a complete set of dummy variables, one for each possible age, sex of the annuitant, and because many annuities are joint and survivor annuities (with benefits continuing as long as either spouse is alive), we also include dummy variables for the age of the spouse.

LTCINS risk: Applications for long-term care insurance policies collect a large amount of information on health status. We have indicators for nearly all such variables. Our controls include, dummy variables for age and spouse's age, whether the respondent is married, or male, and dummy variables indicating low (below 20) and high (above 30) body mass index. We also include indicators of difficulty with a series of activities of daily living (walking, bathing, dressing, eating and toileting, and the total number of such limitations), indicators of use of equipment to help with tasks (a wheelchair, walker, crutches, oxygen, or cane), difficulties with grocery shopping or medication, the number of limitations with respect to instrumental activities of daily living, whether the individual regularly takes prescription drugs, has been injured in a fall, is incontinent, has kidney trouble, congestive heart failure, heart disease, high blood pressure, diabetes, or takes medication for diabetes. Whether he has been diagnosed with cancer, high blood pressure, arthritis, lung disease, currently smokes, has had a hip fracture, has difficulty taking medication, has had a heart attack, takes heart medication, has had a stroke, has psychiatric problems, is cognitively impaired or depressed (Mehta et al., 2002).

Medigap risk: There is no underwriting if a medigap policy is purchased at age 65. We control solely for age. 